\title{
The Principle of Proportionality in International Law
}

\section{Thomas Cottier, Roberto Echandi, Rafael Leal-Arcas, Rachel Liechti, Tetyana Payosova,}

\section{Charlotte Sieber-Gasser}

Abstract

Whilst the principle of proportionality indisputably plays a crucial role in the protection of fundamental rights, it is still unclear to what extent it applies to other fields in international law. The paper therefore explores the role it plays in selected fields of public international law, beyond human rights. The examination begins in the classical domain of reprisals and in maritime boundary delimitation and continues to analyse the role played in the law of multilateral trade regulation of the World Trade Organization and in bilateral investment protection. In an attempt to explain differences in recourse to proportionality in the various fields, we develop in our conclusions a distinction between horizontal and vertical constellations of legal protection.

Research for this paper was funded by the Swiss National Science Foundation under a grant to the National Centre of Competence in Research on Trade Regulation, based at the World Trade Institute of the University of Bern, Switzerland.

NCCR TRADE WORKING PAPERS are preliminary documents posted on the NCCR Trade Regulation website (<www.nccr-trade.org>) and widely circulated to stimulate discussion and critical comment. These papers have not been formally edited. Citations should refer to an "NCCR Trade Working Paper", with appropriate reference made to the author $(s)$.

\section{FNSNF}

FONDS NATIONAL SUISSE 


\title{
The Principle of Proportionality in International Law
}

\author{
Thomas Cottier, Roberto Echandi, Rafael Leal-Arcas, Rachel Liechti, \\ Tetyana Payosova, Charlotte Sieber-Gasser ${ }^{*}$
}

I. Introduction .......................................................................................................................... 4

II. Proportionality in Response to the Use of Force by States......................................6

A. Proportionality in the Resort to Force and Self-Defence (Jus ad Bellum) .................... 7

B. Proportionality in the Conduct of War (Jus in Bello) ............................................ 9

III. Proportionality in Maritime Boundary Delimitation ................................................ 10

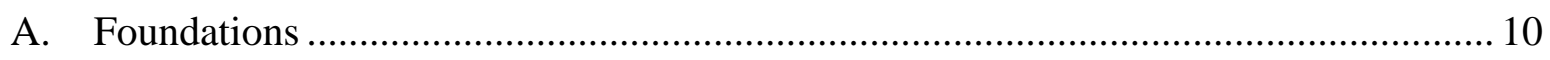

B. Controlling for Disproportionate Allocations .................................................. 11

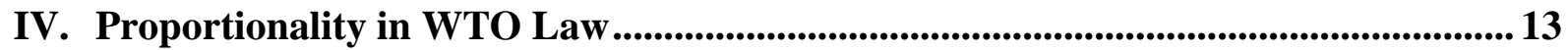

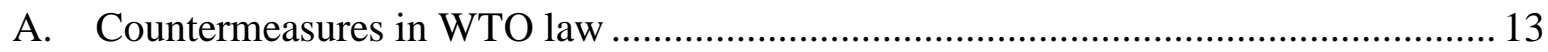

B. Competing Legitimate Policy Goals: Exceptions in GATT and GATS .................... 15

1. Chapeau..................................................................................................................................... 16

2. The Necessity Test ................................................................................................................ 17

3. The Cost-benefit Balancing Test ............................................................................. 18

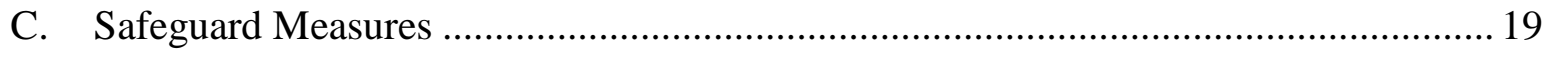

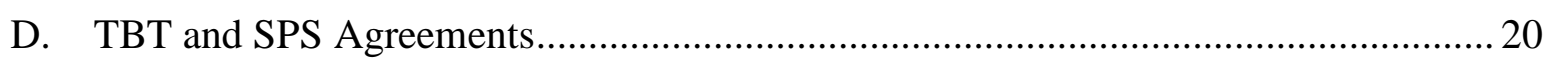

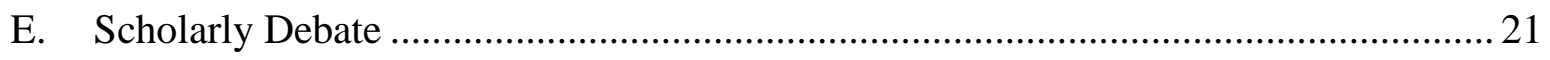

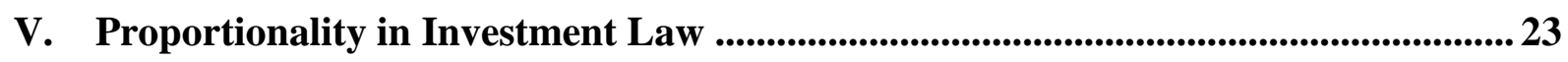

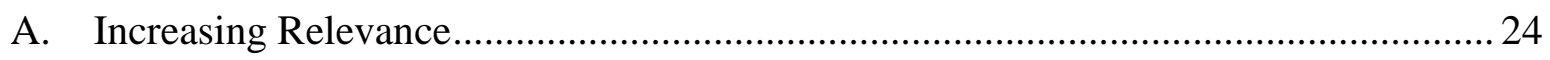

\footnotetext{
* Director, Senior Research Fellows and Research Fellows at the World Trade Institute, University of Bern, NCCR Trade Regulation, respectively. The Swiss National Science Foundation is gratefully acknowledged for funding of the paper. The authors are greatly indebted to Alexia Herwig for her thoughtful comments and suggestions.
} 


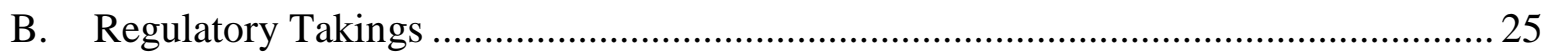

C. Application of the Fair and Equitable Treatment Standard.......................................26

D. General Exceptions on Public Order and Essential Security Interests ........................ 28

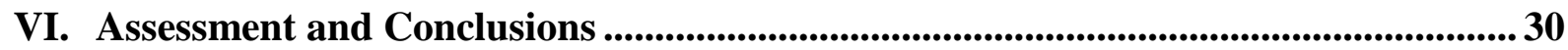




\section{Introduction}

Proportionality is not a catchword in international law. The canon of well-established general principles of law applicable to international law does not generally include proportionality, next to equity, the protection of good faith, legitimate expectations or protection from retroactive application and other principles generally recognized in domestic law. Equally, proportionality has not generally been considered to be part of general principles under customary international law next to sovereign equality, self-determination, non-intervention, the prohibition of use or threat of force, or permanent sovereignty over natural resources. It may achieve such status in the coming years. Its importance is increasing, but the legal status in international law is still unclear. ${ }^{1}$ It remains to be defined whether proportionality operates as a self-standing principle in its own right, as forcefully advocated by the late Thomas Frank, ${ }^{2}$ or whether it merely operates in the context of particular fields of international law and in different ways.

The field of human rights protection, spearheaded by the European Court of Human Rights applying the European Convention on Human Rights has, ever since its establishment, applied considerations of proportionality in assessing restrictions of fundamental rights. The European Court of Justice followed suit in applying human rights in its own jurisdiction, assessing the lawfulness of European Union law. In European law, the concept of proportionality 'implies a means-ends relationship between the aims pursued by a specific action of the government and the means employed to achieve this end'. ${ }^{3}$ The same, albeit to a lesser extent, holds true for protection under the United Nations Human Rights Council and its bodies. Restrictions of human rights are assessed on a case by case basis without expressly employing a comprehensive doctrine of proportionality in state practice. ${ }^{4}$

It is clearly in the protection of fundamental rights where the traditions of proportionality developed in administrative law and, subsequently, constitutional law in continental Europe. It is from here that proportionality found its way into European and public international law, and back from there into domestic law. Human rights protection amounts to the epitome of constitutionalization of public international law as patterns of domestic, administrative and constitutional law were adjusted and translated to become applicable to the law of international relations. ${ }^{5}$ In the field of human rights, the doctrine of multilevel or multilayered governance allows the drawing of a picture of proportionality being applied on all layers of governance in structurally comparable levels. Proportionality has evolved as an important ingredient in consistently assessing human rights violations wherever and on whatever level of

$1 \quad$ Cf. E. Crawford, Proportionality, in: R. Wolfrum (ed.), The Max Planck Encyclopedia of Public International Law, vol. VIII, (2012), at 533.; see for example an analysis of the necessity in the ILC Draft Articles on State Responsibility in R. D. Sloane, 'On the Use and Abuse of Necessity in the Law of State Responsibility’, American Journal of International Law, vol. 106, no. 3, (2012), pp. 447-508, at 504-507.

2 T. M. Franck, 'On Proportionality of Countermeasures in International Law', American Journal of International Law, vol. 102, no. 715, (2008), pp. 715-767, and T. M. Franck, 'Proportionality in International Law’, Law \& Ethics of Human Rights, vol. 4, no. 2, (2010), at 229-242.

3 N. Emiliou, The Principle of Proportionality in European Law: A Comparative Study, Kluwer International, London, (1996), at 23-24.

$4 \quad$ Cf. W. Kälin and J. Künzli, The Law of International Human Rights Protection, Oxford University Press, Oxford, (2009), passim.

5 See J. Klabbers, A. Peters and G. Ulfstein, The Constitutionalization of International Law, Oxford University Press, Oxford, (2009). 
governance they occur. Courts regularly apply the principle and its different components in this context. Proportionality is being used to assess whether restrictions and measures affecting human rights appropriately respond to legitimate public interests. The three-tier test of proportionality as developed in general administrative and constitutional law, in particular in Germany, may be found to apply in this field: under the principle of suitability, it is established whether a specific measure taken by the government is suitable for a legitimate government purpose. Under the principle of necessity, the question raised is whether there are less intrusive means at hand to achieve the purpose of the measure. The principle of necessity requires that no less restrictive measure, which is equally effective, is available. Finally, the principle of proportionality stricto sensu evaluates whether a measure is excessive and attributes relative weight to each principle involved, therewith taking into account all available factors and preventing unreasonable results. 'The greater the degree of non-satisfaction of, or detriment to, one principle, the greater must be the importance of satisfying the other' ${ }^{6}$ Responding to proportionality, restrictions therefore need to be suitable and apt and able to achieve the goal (Suitability: Zwecktauglichkeit). They need be necessary to achieve such goals, not going beyond what is required (Necessity: Erforderlichkeit). Finally, they need to be appropriate, balancing the purpose and impact (Proportionality in a narrow sense:

Zumutbarkeit). ${ }^{7}$ The triad, developed in German law, has increasingly influenced perceptions in restricting human rights throughout Europe and the world. For example, citizens in the UK find an explanation of proportionality newly introduced in common law based on the interpretation of the Human Rights Act. According to the latter the means of pursuing a legitimate objective shall not be excessive, arbitrary or unfair - 'You must not use a sledgehammer to crack a nut'. ${ }^{8}$

The adoption of proportionality on all layers of human rights protection alike does not mean that the doctrine is firmly settled and uncontroversial. It is feared that the allegedly objective process of weighing and balancing of interests inherent to the three-tier test of proportionality ${ }^{9}$ runs the risk of avoiding important moral and value judgment and eventually leads to an erosion of human rights protection. ${ }^{10}$ But importantly, the methodological debate no longer differentiates between domestic and international law in the field of human rights. Both levels share common concerns as to how the principle of proportionality affects individual rights as well as the regulatory powers of legislators. Both levels share a concern for correctly defining the proper role of courts and of proper standards of judicial review.

While established doctrines of proportionality are mostly applied to international human rights similar to domestic law, it is much less clear to what extent proportionality applies to other fields in international law. It is unclear to what extent proportionality may be deemed a general principle of international law applicable to all fields alike. It is unclear to what extent

R. Alexy, A Theory of Constitutional Rights, Oxford University Press, Oxford, (1986), at 102. E.g. P. Tschannen, U. Zimmerli and M. Müller, Allgemeines Verwaltungsrecht, Third Edition, Staempfli, Bern, (2009), at 152.

Interpreting the Human Rights Act, http://www.thevillage.org.uk/hrinterpreting.htm (visited March 8, 2012).

R. Alexy, 'The Construction of Constitutional Rights', Law and Ethics of Human Rights, vol. 4, no 1, (2010), at 21-32.

For a comprehensive analysis see J. Christoffersen, Fair Balance, Proportionality, Subsidiarity and Primarity in the European Convention on Human Rights, Martin Nijhoff Publishers, Leiden, (2009); S. Tsakyrakis, Proportionality: An Assault on Human Rights?, Jean Monnet Working Paper 09/08, (2009), www.jeanmonnetprogram.org (visited March 8, 2012); see also: J. Christoffersen and M. R. Madsen, The European Court of Human Rights Between Law and Politics, Oxford University Press, Oxford, (2011). 
it applies under different names or in disguise. It is unclear to what extent the same methodological problems encountered in the field of fundamental and human rights also determine and shape the role of proportionality in other chapters of international law. The three-step test entails considerable powers in assessing suitability, necessity and appropriateness of state conduct, and it is far from clear whether it is suitable for application horizontally to all fields of public international law. The paper therefore seeks to assess the role of proportionality in selected areas of public international law other than human rights protection. We look into the classical domain of sanctions and reprisals in response to violations of international law. We assess the role of proportionality in the law of the sea, in the law of multilateral trade regulation of the World Trade Organization and in bilateral investment protection. We primarily look into recourse to proportionality by arbitral tribunals and courts, seeking evidence. We are interested to learn whether there are differences in applying proportionality. We draw appropriate conclusions in assessing the operation of proportionality in these different fields of public international law. In particular, we shall develop in our conclusions a distinction between horizontal and vertical constellations of legal protection which, in our view, assists in explaining differences in recourse to proportionality in different fields of public international law and the absence of a general principle of proportionality in domestic law and in the special field of international human rights protection.

\section{II.Proportionality in Response to the Use of Force by States}

Under international law, states are obliged to refrain from threatening or using force against the territorial integrity or political independence of any other state in their international relations. This obligation is now recognized to constitute a principle of customary international law and is universally binding. ${ }^{11}$ Today the principle is codified in Article 2(4) of the Charter of the United Nations. As the principle does not affect the right of a state to maintain order within its own jurisdiction, nor to defend itself against unlawful attacks, it has been accepted - since the UN Charter was established - that there are three categories of 'force' which may be legitimate. These are: retorsions, reprisals and self-defence. ${ }^{12}$ Such force is employed in a horizontal manner, and it is interesting to observe that state practice and arbitration rendered them subject to the principle of proportionality.

The principle of self-defence is not only an integral part of customary law, but is also stated in Article 51 of the UN Charter. ${ }^{13}$ It constitutes the only explicit exception to the basic principle of refraining from the threat or use of force. In contrast to retorsion, which is an unfriendly, but nonetheless lawful measure, both reprisals and self-defence must fulfil certain preconditions to be legitimate. For self-defence these are 'armed attack' against a state; the

See N. Stürchler, The Threat of Force in International Law, Cambridge University Press, Cambridge, (2007); M. N. Shaw, International Law, Fifth Edition, Cambridge University Press, Cambridge, (2006), at 1018.

E.g. M. N. Shaw (2006) supra note 11, at 1022-1036 for an in-depth analysis of the categories. 'Nothing in the present Charter shall impair the inherent right of individual or collective self-defence if an armed attack occurs against a Member of the United Nations, until the Security Council has taken measures necessary to maintain international peace and security. Measures taken by Members in the exercise of this right of self-defence shall be immediately reported to the Security Council and shall not in any way affect the authority and responsibility of the Security Council under the present Charter to take at any time such action as it deems necessary in order to maintain or restore international peace and security.' 
core of, and limit to, the right are the concepts of necessity and proportionality. ${ }^{14}$ It is here that the principle finds its locus classicus and point of departure in international law. As outlined below it entered international law through the application by international tribunals of the principle of equity.

\section{A. Proportionality in the Resort to Force and Self-Defence (Jus ad Bellum)}

In the Naulilaa Arbitration between Portugal and Germany in $1928,{ }^{15}$ for the first time a Tribunal held that there was no applicable law of nations dealing with the legitimacy of reprisals of states and therefore decided to fill the gap by consulting the principles of equity in analogy:

Enfin, à défaut de règles du droit des gens applicables aux faits litigieux, les arbitres estiment devoir combler la lacune, en statuant suivant les principes d'équité, tout en restant dans le sens du droit des gens, appliqué par analogie, et en tenant compte de son évolution. ${ }^{16}$

The next step taken by the Tribunal was to give a classic definition of reprisals and the various elements to be taken into account. A reprisal is a lawful act of self-defence of an injured state only if it takes place in response to a prior violation of international law, and after peaceful negotiations have been unsuccessful. It is bordered by experiences of humanity and the rules of good faith applicable in relations between states. It would be illegal without such prior violation of international law. ${ }^{17}$ This definition, however, does not specify whether the act of self-defence needs to be proportionate to the original unlawful act or not. A prohibition of abuse of the right was introduced, taking into account the experience of World War I. The Tribunal decided that even if proportionality to the original unlawful act was not required by the law of nations, reprisals should certainly be considered as excessive and therefore unlawful when they are out of all proportion to the act that motivates them. ${ }^{18} \mathrm{In}$ conclusion, the Tribunal found that the German raid on Angola, which had been provoked by the mistaken killing of three Germans, was not a proportionate response and that no attempts at peaceful negotiations had preceded it. The reprisal was therefore found to be unlawful. ${ }^{19}$

The International Court of Justice (hereinafter, the ICJ) dealt with the question of self-defence for the first time in 1986 in the Nicaragua case. ${ }^{20}$ Before examining the concrete measures at hand the Court stated that the 'Parties also agree in holding that whether the response to the attack is lawful depends on observance of the criteria of the necessity and the proportionality

See e.g. M. N. Shaw (2006), supra note 11, at 1031. There is still no consensus on pre-emptive selfdefence, while some consider it possible if an armed attack has been imminent and unavoidable. See e.g. M. N. Shaw (2006), supra note 11, at 1028-1030; A. Cassese, International Law in a Divided World, Clarendon Press, Oxford, (1986), at 230 et seq. Responsabilité de L’Allemagne a Raison des Dommages Causés dans les Colonies Portugaises du Sud de L’Afrique, 8 Trib. Arb. Mixtes 409 (1928) (Portugal v. Germany) (The Naulilaa Arbitration), reprinted in 2 R. Int'l Arb. Awards 1011 (1949).

Ibid., at 1016.

Ibid., at 1026.

Ibid.

Ibid., at 1028.

Military and Paramilitary Activities in and against Nicaragua (Nicaragua v. United States of America). Merits, Judgment. I.C.J. Reports 1986, at 14; See also a detailed account by T. M. Franck (2010), supra note 2 . 
of the measures taken in self-defence. ${ }^{21}$ First the Court pointed out that US assistance to the 'contras' as well as the mining of Nicaraguan ports and attacks on ports, oil installations and more by the US had been unlawful because there had been no armed attack on the part of Nicaragua against El Salvador. It nonetheless continued to examine whether the US measures would have been deemed necessary and proportionate, had they been lawful in the first place. The Court noted that the US actions took place several months after the opposition against the government of El Salvador was stopped. ${ }^{22}$ Thus the component of necessity was absent in this case. On the issue of proportionality the Court stated the following:

237 ... Whatever uncertainty may exist as to the exact scale of the aid received by the Salvadorian armed opposition from Nicaragua, it is clear that these latter United States activities in question could not have been proportionate to that aid. Finally on this point, the Court must also observe that the reaction of the United States in the context of what it regarded as self-defence was continued long after the period in which any presumed armed attack by Nicaragua could reasonably be contemplated.

The Court summarized its findings that the 'acts of which Nicaragua is accused, even assuming them to have been established by and imputable to that State, could only have justified proportionate counter-measures on the part of the State which had been the victim of these acts, namely El Salvador, Honduras or Costa Rica. They could not justify countermeasures taken by a third State, the United States, and particularly could not justify intervention involving the use of force. ${ }^{23}$

In 2005 the Democratic Republic of Congo claimed to have been attacked by armed Ugandan forces in the Congo case. ${ }^{24}$ Uganda on the other hand pleaded self-defence against attacks from the Allied Democratic Forces for the Liberation of the Congo (ADF). As the Court was not satisfied that any attack had emanated from armed forces of the Congo, it denied Uganda the right of self-defence. It once again seized the opportunity of observing that the measures taken would neither seem proportionate nor necessary:

147. For all these reasons, the Court finds that the legal and factual circumstances for the exercise of a right of self-defence by Uganda against the DRC were not present. [...] The Court cannot fail to observe, however, that the taking of airports and towns many hundreds of kilometres from Uganda's border would not seem proportionate to the series of transborder attacks it claimed had given rise to the right of self-defence, nor to be necessary to that end.

In the case law of the ICJ, self-defence is clearly restricted to measures that are necessary and proportionate. To qualify as necessary, an armed attack from a state must have taken place

Nicaragua, supra note 20, para. 194.

Nicaragua, supra note, 20, para. 237.

Nicaragua, supra note, 20, para. 249. In addition to the already mentioned preconditions for selfdefence, the collective self-defence rests upon two additional criteria - explicit declaration by the statevictim about an armed attack and assistance request directed to a third state, which were not met in this case, - see Nicaragua, supra note, 20, paras. 195-199.

Armed Activities on the Territory of the Congo (Democratic Republic of the Congo v. Uganda), Judgment, I.C.J. Reports 2005, at 168. 
and to qualify as proportionate, the self-defence should not exceed what is necessary to fend off the attack. The rights of the Security Council to take measures necessary to maintain international peace and security remain reserved. ${ }^{25}$

In conclusion, it is well established in case law that the right to self-defence is subject to the principle of necessity and proportionality. This was explicitly recognized by the ICJ. Upon request of the General Assembly of the United Nations, the ICJ rendered an Advisory Opinion on the Legality of the Threat or Use of Nuclear Weapons in July $1996 .{ }^{26}$ After clarifying that the UN Charter is 'the most directly relevant applicable law', ${ }^{27}$ it reiterated that ' $[t]$ he submission of the exercise of the right of self-defence to the conditions of necessity and proportionality is a rule of customary international law. ${ }^{28}$

\section{B. Proportionality in the Conduct of War (Jus in Bello)}

In the law of warfare, enforcing self-defence, the principle of proportionality aims, on the one hand, at prohibiting the use of certain weapons which are particularly destructive and, on the other hand, at limiting the harm done by weapons that are not prohibited.

The Advisory Opinion of the ICJ on the Legality of the Threat or Use of Nuclear Weapons found that the proportionality principle did not in itself exclude the use of nuclear weapons in all circumstances. It did however emphasize that a use of force which is proportionate under the law of self-defence, 'must, in order to be lawful, also meet the requirements of the law applicable in armed conflict which comprise in particular the principles and rules of humanitarian law. ${ }^{29}$ According to the Court, the first principle is based on the distinction between combatants and non-combatants, aiming at the protection of the civilian population. The civilian population is never to be an object of attack, and the use of weapons that cannot distinguish between combatants and non-combatants is banned. The second principle prohibits causing unnecessary suffering to combatants and civilians. The prohibition of weapons that do not meet these requirements of humanitarian law can thus be seen as a reflection of the principle of proportionality. After a detailed examination of humanitarian law, however, the Court was unable to 'reach a definitive conclusion as to the legality or illegality of the use of nuclear weapons by a State in an extreme circumstance of self-defence, in which its very survival would be at stake. ${ }^{30}$

In 2003, in the Oil Platforms ${ }^{31}$ case, the ICJ again reaffirmed the requirement of necessity and proportionality. Only an armed attack in the responsibility of a state makes a measure of selfdefence necessary, and even then, this measure needs to be proportional to the armed attack in terms of means and timing. In the case at hand, the US launched a sequence of military action against Iranian vessels and aircraft. This action was found to be disproportionate to the damage suffered by a US vessel in the Persian Gulf.

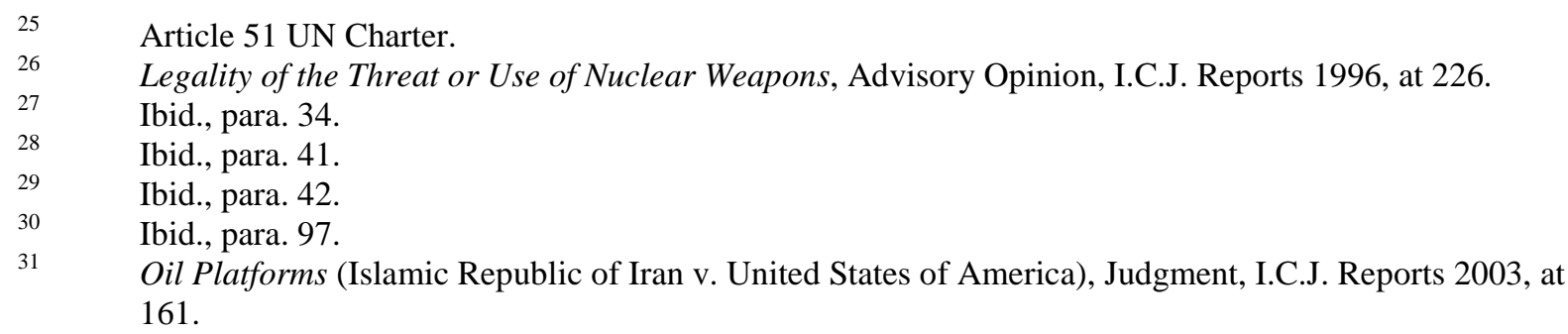


77. [...] As a response to the mining, by an unidentified agency, of a single United States warship, which was severely damaged but not sunk, and without loss of life, neither "Operation Praying Mantis" as a whole, nor even that part of it that destroyed the Salman and Nasr platforms, can be regarded, in the circumstances of this case, as a proportionate use of force in self-defence.

In conclusion, the classical body of international law in the fields of self-defence, armed intervention and warfare essentially focuses, founded upon equity, on the principle of necessity, assessing the relationship of means as applied to achieve a particular and lawful end, taking into account the principles of humanitarian law. Proportionality as recognised by the ICJ as a principle of customary law does not entail an assessment of suitability and an overall balance of interests at stake in this field of public international law.

\section{Proportionality in Maritime Boundary Delimitation}

One particular aspect of territorial sovereignty of states - against which states are obliged to refrain from threatening or using force - is maritime boundary delimitation. ${ }^{32}$ As delimitation generally affects more than one state, the delimitation must be based on peaceful settlement among all the states involved. In cases where they are unable to arrive at an agreement, courts must be called upon. Again, equity was at the heart of introducing considerations of proportionality in allocating marine spaces to coastal states, entailing the employment of criteria and relevant factors.

\section{A. Foundations}

In 1969, in the North Sea Continental Shelf ${ }^{33}$ cases, the ICJ was requested to state the rules and principles of international law applicable in a dispute related to the delimitation of the continental shelf. ${ }^{34}$ The Court decided two cases in a single judgment, one between Germany and the Netherlands and the other between Germany and Denmark. Most of the delimitation had been agreed upon by the parties. The court had to choose between the equidistance principle (supported by Denmark and the Netherlands) or proportionality to the coastline (Germany) in order to set the rest of the boundaries. ${ }^{35}$

After having come to the conclusion that the parties were under no obligation to apply the equidistance principle, neither under treaty nor customary law, ${ }^{36}$ the Court contended that the

For a detailed study on the law of the sea, see e.g. M. N. Shaw (2006), supra note 11, at 490-568. North Sea Continental Shelf, Judgment, I.C.J. Reports 1969, at 3.

More recent works on this extensive and complex subject include R. Kolb, Case Law on Equitable Maritime Delimitation/Jurisprudence sur les délimitations maritimes selon l'équité, Digest and Commentaries/Répertoire et commentaries, Martinus Nijhoff Publishers, Leiden, (2003); M. Antunes, Towards the Conceptualisation of Maritime Delimitation, Legal and Technical Aspects of a Political Process, Martinus Nijhoff Publishers, Leiden, (2003); J. Shi, 'Maritime Delimitation in the Jurisprudence of the International Court of Justice', Chinese Journal of International Law, vol. 9, no. 2, (2010), pp. 271-291; T. Cottier, Equitable Principles of Maritime Boundary Delimitation: Legal Foundations and Methodology, (forthcoming 2013). North Sea Continental Shelf, supra note 33, para. 7. Ibid., para. 83. 
parties were obliged to take all of the circumstances in the particular case into account and to act in such a way that the equitable principles were applied, ${ }^{37}$ and therefore decided:

(D) in the course of the negotiations, the factors to be taken into account are to include: ...

(3) the element of a reasonable degree of proportionality, which a delimitation carried out in accordance with equitable principles ought to bring about between the extent of the continental shelf areas appertaining to the coastal State and the length of its Coast measured in the general direction of the coastline, account being taken for this purpose of the effects, actual or prospective, of any other continental shelf delimitations between adjacent States in the same region. ${ }^{38}$

\section{B. Controlling for Disproportionate Allocations}

Ten years later, in the Anglo-French Continental cases, ${ }^{39}$ the Court of Arbitration stated even more precisely that it did not consider proportionality to be a general principle to be applied in all cases. It recognized that in the North Sea Continental Shelf cases there was a peculiar geographical situation, while:

99. ... In the present case, the role of proportionality in the delimitation of the continental shelf is, in the view of this Court, a broader one, not linked to any specific geographical feature. It is rather a factor to be taken into account in appreciating the effects of geographical features on the equitable or inequitable character of a delimitation and in particular of a delimitation by application of the equidistance method.

The Court continued to state that the concept of proportionality plays a particular role in the situations of 'particular configurations of the coast or individual geographical features'.

100. ... The concept of "proportionality" merely expresses the criterion or factor by which it may be determined whether such a distortion results in an inequitable delimitation of the continental shelf as between the coastal States concerned. The factor of proportionality may appear in the form of the ratio between the areas of continental shelf to the lengths of the respective coastlines, as in the North Sea Continental Shelf cases. But it may also appear, and more usually does, as a factor for determining the reasonable or unreasonable - the equitable or inequitable - effects of particular geographical features or configurations upon the course of an equidistance-line boundary.

Ibid., para. 93-99.

Ibid., para. 101.

Anglo-French Continental Shelf Arbitration (1979) 18 ILM at 379-494. 
101. In short, it is disproportion rather than any general principle of proportionality which is the relevant criterion or factor.

The Court specified that it was more a question of remedying disproportionality and inequitable effects produced by particular geographical configurations or features, and that the concept of proportionality was not to be used 'as a general principle providing an independent source of rights to areas of continental shelf'. ${ }^{40}$

Recourse to proportionality - or rather disproportionality - was further developed in a subsequent case of the ICJ and in arbitration. The 2009 Case Maritime Delimitation in the Black Sea (Romania v. Ukraine) ${ }^{41}$ offers a succinct summary of the case law at hand and recalls that proportionality merely applies to avoid gross inequities and does not entail a mathematical application of a principle. Upon reviewing a number of precedents, the Court recalled in particular the findings of the Chamber in the 1984 Gulf of Maine Case, which confirmed that the equitable principles 'may be taken into consideration for an international maritime delimitation' in cases of certain geographical inequalities. ${ }^{42}$ Finally, the Chamber stated:

167. [...] The Chamber's views on this subject may be summed up by observing that a maritime delimitation can certainly not be established by a direct division of the area in dispute proportional to the respective lengths of the coasts belonging to the parties in the relevant area, but it is equally certain that a substantial disproportion to the lengths of those coasts that resulted from a delimitation effected on a different basis would constitute a circumstance calling for an appropriate correction. (Ibid., p. 323, para. 185; emphasis added.)

These cases demonstrate how the ICJ and arbitration tribunals developed their jurisprudence in the field of maritime delimitation based upon the equitable principles. The ICJ developed a multi-step examination, the result of which is subject to a disproportionality check. Firstly, the Court ascertains that the states concerned have not themselves been able to come to an agreement. Secondly, it determines the relevant coasts and base points to be used, and as a rule establishes a provisional equidistance. Thirdly, the Court takes all relevant circumstances into consideration before it decides whether the provisionally drawn line needs to be modified. Finally the Court verifies ex post, whether the result 'does not lead to any significant disproportionality by reference to the respective coastal lengths and the apportionment of areas that ensue. ${ }^{43}$

In conclusion, proportionality in maritime boundary delimitation assumes a particular and succinct function in this field of natural resource allocation. Consideration of suitability and necessity are absent from the test. The focus is on broadly assessing whether the results achieved are equitable and not disproportionate in relation to coastal configurations and the landmass of coastal states.

\footnotetext{
$40 \quad$ Ibid., para. 101.

$41 \quad$ Maritime Delimitation in the Black Sea, Judgment, ICJ Rep. 2009 p. 61.

$42 \quad$ Ibid., para. 167.

$43 \quad$ Ibid., para. 210.
} 


\section{Proportionality in WTO Law}

WTO law does not explicitly operate on the basis of proportionality, but contains several indirect references, generally expressed in terms like 'necessary to' or 'least trade restrictive', or 'appropriate' measures. Such terms illustrate the inherent presence of some kind of proportionality in WTO law by reference to balancing and weighing of measures or interests. References to proportionality come in the form of three versions of obligations: (i) public policy exceptions (Article XX General Agreement on Tariffs and Trade (GATT) and Article XIV General Agreement on Trade in Services (GATS), which require a certain degree of weighing in order to establish whether or not a divergence from WTO obligations is legitimate, and (ii) positive obligations (e.g. in the SPS and the TBT Agreement), which commit Members to conduct a careful balancing or weighing test before implementing a specific measure. Finally (iii), proportionality can be observed in the context of suspension of concessions in enforcing WTO law under the Dispute Settlement Understanding (DSU).

Against this background we turn to the analysis of proportionality in WTO law. Three steps of the proportionality principle can be identified: (i) the characterization of a causal link between the measures attacked and the policy aim justifying the exception; (ii) the requirement of least-possible effect on international trade taking into consideration the policy aim; (iii) a balance estimate of the proportionality of the measure. ${ }^{44}$ The following paragraphs illustrate different references and how the Appellate Body and Members have interpreted them. ${ }^{45}$ Given the prominence of proportionality in the law of reprisals and countermeasures discussed above, we begin with implementation and enforcement of WTO dispute settlement decisions, and then turn to substantive law within the GATT and the GATS.

\section{A. Countermeasures in WTO law}

In the DSU, proportionality is relevant for the establishment of a penalty or countermeasure: 'The level of the suspension of the concessions or other obligations authorized by the DSB shall be equivalent of the level of nullification or impairment'. ${ }^{46}$ Thus, in every dispute where the Dispute Settlement Body (DSB) decides upon compensation and suspension of concessions, a test weighing the gravity of the injury of the different measures at stake has to be conducted. The establishment of the right measures, thus, mainly consists of considerations of proportionality.

In EC-Bananas III the arbitrators established that the DSU rules on countermeasures have to be interpreted in a way that avoids conflict with customary international law:

44

See generally M. Andenas and S. Zleptnig, 'Proportionality: WTO Law: In Comparative Perspective', Texas International Law Journal, vol. 42, no. 3, (2007), 371-427; N. Diebold, Non-discrimination in International Trade in Services: 'Likeness' in WTO/GATS, Cambridge University Press, Cambridge, 2010.

45

For an overview of WTO provisions, which may incorporate proportionality see A. D. Mitchell, Legal Principles in WTO Disputes, Cambridge University Press, Cambridge, (2008), at 178-181; and on the necessity element see a more recent article: A. D. Mitchell and C. Henckels, 'Variations on a Theme: Comparing the Concept of "Necessity” in International Investment and WTO Law', Chicago Journal of International Law (forthcoming, 2013), available at: 
Moreover, such cumulative compensation or cumulative suspension of concessions by different WTO Members for the same amount of nullification or impairment would run counter to the general international law principle of proportionality of countermeasures. $^{47}$

Thus, the penalty should not be disproportionate to the harm caused. ${ }^{48}$ However, in deviation from customary international law, the gravity of a wrongful act is subordinate in WTO law. Rather, WTO law imposes a restriction on the punitive character of countermeasures by requiring that such measures must be 'equivalent to the level of nullification or impairment'. The focus is thus on the gravity of the injury, and not on the gravity of the wrongful act. ${ }^{49}$ Mitchell argues that if the principle of proportionality were considered thoroughly, the degree of culpability would have to be taken into consideration when establishing whether or not a penalty or countermeasure is disproportionate. However, this has so far not been the case. ${ }^{50}$

In US-Cotton Yarn, the Appellate Body referred to customary international law in refuting the concept of punitive damages in WTO law:

Our view is supported further by the rules of general international law on state responsibility, which require that countermeasures in response to breaches by states of their international obligations be commensurate with the injury suffered. In the same vein, we note that Article 22.4 of the DSU stipulates that the suspension of concessions shall be equivalent to the level of nullification or impairment. This provision of the DSU has been interpreted consistently as not justifying punitive damages. These two examples illustrate the consequences of breaches by states of their international obligations, whereas a safeguard action is merely a remedy to WTO-consistent "fair trade" activity. It would be absurd if the breach of an international obligation were sanctioned by proportionate countermeasures, while, in the absence of such breach, a WTO Member would be subject to a disproportionate and, hence, "punitive", attribution of serious damage not wholly caused by its exports. In our view, such an exorbitant derogation from the principle of proportionality in respect of the attribution of serious damage could be justified only if the drafters of the ATC had expressly provided for it, which is not the case. ${ }^{51}$

In the Agreement on Subsidies and Countervailing Measures (SCM), the language concerning countermeasures is somewhat different to the DSU: While the DSU requires countermeasures to be 'equivalent' to the injury, countermeasures must be 'appropriate' ${ }^{52}$ in respect to

$47 \quad$ EC-Bananas III, WT/DS27/ARB (April 9 1999), para. 6.16.

48 A. D. Mitchell, 'Proportionality and Remedies in WTO Disputes', The European Journal of International Law, vol. 17, no. 5, (2007), 985-1008, at 999.

49 A. Desmedt, 'Proportionality in WTO Law', Journal of International Economic Law, vol. 4, no. 3, (2001), 441-480, at 448.

A. D. Mitchell (2007), supra note 48, at 1001-4.

United States-Transitional Safeguard Measure on Combed Cotton Yarn from Pakistan, WT/DS192/AB/R (October 8 2001), para. 120, footnotes omitted.

Articles 4.10 and 4.11 SCM Agreement. 
prohibited subsidies and 'commensurate" ${ }^{53}$ referring to actionable subsidies under the SCM Agreement. ${ }^{54}$ Footnotes 9 and 10 of the SCM Agreement clarify that the reference to 'appropriate' 'is not meant to allow countermeasures that are disproportionate in the light of the fact that the subsidies dealt with under these provisions are prohibited'. These are the only two explicit references to proportionality in WTO law.

In Brazil-Aircraft arbitrators further elaborated the term 'appropriate' under the SCM Agreement and came to the conclusion that the SCM Agreement does not require countermeasures to be equivalent to the injury and, thus, they may go beyond countermeasures under the DSU. In order to establish 'appropriate' countermeasures by including all possibilities at hand, the Panel will increasingly have to include proportionality in its considerations:

[...] [W]e note that footnotes 9 and 10 at least confirm that the term "appropriate" in Articles 4.10 and 4.11 of the SCM Agreement should not be given the same meaning as the term "equivalent" in Article 22 of the DSU. ${ }^{55}$

[...] [W]e recall that the concept of nullification or impairment is absent from Articles 3 and 4 of the SCM Agreement. In that framework, there is no legal obligation that countermeasures in the form of suspension of concessions or other obligations be equivalent to the level of nullification or impairment. ${ }^{56}$

\section{B. Competing Legitimate Policy Goals: Exceptions in GATT and GATS}

Article XX GATT states the conditions for exemptions from GATT regulation. Panels and the Appellate Body use a three-step analysis. They first examine whether the policy measures is covered by one of the motives listed. Secondly, they assess whether the required test of necessity or relatedness is fulfilled. Thirdly, they establish whether the measure complies with the chapeau of the provision. The same methodology applies to Article XIV GATS ${ }^{57}$ First, the measure needs to be justified under the specific provisions of the Article. However, GATS Article XIV only provides for a single degree of connection, i.e., 'necessary to', while GATT Article XX differentiates between 'necessary to' and 'relating to'. The latter is of paramount importance in defining the relationship of trade and the environment. ${ }^{58}$ Elements of

$53 \quad$ Ibid.

$54 \quad$ A. Desmedt (2001), supra note 49, at 451.

$55 \quad$ Brazil-Aircraft, WT/DS46/ARB (August 28 2000), para. 3.51.

$56 \quad$ Brazil-Aircraft, supra note 55, para. 3.57.

57 United States-Measures Affecting the Cross-Border Supply of Gambling and Betting Services, WT/DS285/AB/R (April 7 2005), para. 292; See also J. Trachtman, 'International Decisions - United States: Measures Affecting the Cross-Border Supply of Betting and Gambling Services’, American Journal of International Law, vol. 99, no. 4, (2005), 861-867, at 864; Committee on Trade and Environment, GATT/WTO Dispute Settlement Practice Relating to Article XX, Paragraphs (b), (d) and (g) of GATT, Note by the Secretariat, Revision, WT/CTE/W/53/Rev.1 (October 26 1998), para. 10. See generally for the three-step test, T. Cottier and M. Oesch, International Trade Regulation, Cameron May and Staempfli, Bern and London, (2005), at 429. For a criticism of the utility of the approach see P. Mavroidis, The General Agreement on Tariffs and Trade: A Commentary, Oxford University Press, Oxford, (2005), at 213.

T. Cottier, P. Delimatsis and N. Diebold, ‘Article XIV GATS: General Exceptions’, in R. Wolfrum, PT. Stoll and C. Feinäugle (eds.), Trade in Services, Max Planck Commentaries on World Trade Law, Martinus Nijhoff Publishers, Leiden and Boston, vol. 6, (2008), 287-328, at 292. 
proportionality can be found in both of the steps for assessing exemptions to GATT and GATS. The relationship of proportionality to necessity, however, is not settled. It is unclear whether necessity in WTO entails, in essence, an analysis amounting to a three-step proportionality principle, whether it goes beyond it or falls short of it. Andenas and Zleptnig consider the different tests embodied in Article XX GATT - when taken together - to be 'more refined and structured' than the proportionality analysis in the same test in EC law, Interstate U.S. law or general public international law. ${ }^{59}$ We first assess the relevance of the chapeau provisions for proportionality.

\section{ChAPEAU}

The Chapeau of Article XX GATT states that given that such measures 'are not applied in a manner which would constitute a means of arbitrary or unjustifiable discrimination' or a 'disguised restriction in international trade', GATT shall not prevent domestic measures which serve a specific objective of general interest, ${ }^{60}$ like the protection of public morals. Several terms (e.g. 'unjustifiable', 'arbitrary' or 'necessary') in Article XX GATT require weighing and balancing along the lines of the proportionality principle. Article XIV GATS is the services equivalent of GATT Article XX. Accordingly, it shows similarities in the application of proportionality. ${ }^{61}$

In US-Shrimp, the Appellate Body's interpretation of the weighing and balancing test in the chapeau of Article XX GATT comes very close to the principle of proportionality, which is referred to as 'a line of equilibrium'. This line shall not cancel out the competing rights and thus shall not distort the balance between the rights and obligations reached by the Members in GATT. Since the factual circumstances vary, the equilibrium is determined on a case-bycase basis. $^{62}$

The chapeau of GATT XX indicates that invoking an exception to GATT requires the application of measures in a reasonable manner, taking into account national rights, but also the rights of other Members of the GATT. This act of balancing will ultimately determine whether a measure is arbitrary, unjustifiable or constitutes a disguised restriction on international trade. This process closely resembles a proportionality analysis. Thus, within the scope of Article XX GATT and Article XIV GATS, proportionality 'can be seen as a governing principle and flexible tool to guide judicial inquiry into lawfulness of domestic measures' ${ }^{63}$ Essentially, it is a guarantee against the abuse of rights which in turn is founded in equity. ${ }^{64}$

M. Andenas and S. Zleptnig (2007), supra note 44, at 415-6. Chapeau of GATT XX.

The prudential carve-out in paragraph two of the Annex on Financial Services could also be potentially affected, see C. Kaufmann and R. H. Weber, 'Reconciling Liberalized Trade in Financial Services and Domestic Regulation,' in K. Alexander and M. Andenas (eds.), The World Trade Organisation and Trade in Services, Martinus Nijhoff Publishers, Leiden, (2008), at 411-427.

US-Shrimps, WT/DS58/AB/R (October 12 1998), para. 159.

M. Andenas and S. Zleptnig (2007), supra note 44, at 415.

US-Shrimps, supra note 62, para. 158. 'The Chapeau of Article XX is, in fact, but one expression of the principle of good faith. The principle, at once a principle of law and a general principle of international law, controls the exercise of rights by states. One application of this general principle, the application widely known as the doctrine of abus de droit, prohibits the abusive exercise of a state's rights and enjoins that whenever the assertion of a right 'impinges on the field covered by [a] treaty obligation, it must be exercised bona fide, that is to say, reasonably' (footnotes omitted). See generally M. Panizzon, Good Faith in the Jurisprudence of the WTO, Hart, Oxford and Portland, (2006). 


\section{THE NECESSITY TEST}

The necessity test in Article XX GATT evolved from the Korea-Beef and EC-Asbestos cases. ${ }^{65}$ It consists of a three-step analysis which takes up the three elements of the principle of proportionality identified at the outset: (i) Is the measure suitable to achieve the goal? (ii) is the measure necessary or are there less trade restrictive measures available to achieve the same goal? and (iii) It requires 'a process of weighing and balancing'

[...] a series of factors which prominently include the contribution made by the compliance measure to the enforcement of the law or regulation at issue, the importance of the common interests or values protected by that law or regulation, and the accompanying impact of the law or regulation on imports or exports. ${ }^{66}$

In Korea-Beef, the first case to deal with the issue, the Appellate Body stressed that a process of weighing and balancing contributes to determining whether a Member can reasonably be expected to employ an alternative measure, or whether a less WTO-inconsistent measure is reasonably available. ${ }^{67}$ Thus, it might seem that step three of the necessity test constitutes some kind of proportionality test. However, it is also argued that the third step merely suggests that all the relevant factors must be taken into account in the analysis of the necessity of a given measure. ${ }^{68}$

The $E C$-Asbestos case refined the necessity requirement, stating that: 'in determining whether a suggested alternative measure is "reasonably available", several factors must be taken into account, besides the difficulty of implementation' ${ }^{69}$ Based on Korea-Beef, the main factors that need to be taken into account are: (i) the extent to which the alternative measure contributes to the realization of the end pursued, and (ii) the importance of the interests and values pursued by the Member. ${ }^{70}$ Furthermore, two important cases from the 1990s considered necessity under Article XX(d) GATT. Both Thailand-Cigarettes ${ }^{71}$ and USGasoline $^{72}$ confirmed that the measure consistent or less inconsistent with the WTO law shall be reasonably available in achieving legitimate objectives.

The main case that covers proportionality-related matters in the GATS is US-Gambling. ${ }^{73}$ It presents a definition of the necessity condition equivalent to the one presented in Korea-Beef under GATT Article XX. ${ }^{74}$ Consequently, both the cost-benefit balancing test and the two-tier test are applied similarly and controlled against a 'less-restrictive alternative' test.

EC-Measures Affecting Asbestos and Asbestos-Containing Products, WT/DS135(AB/R (March 12 2001).

Korea-Measures Affecting Imports of Fresh, Chilled and Frozen Beef, WT/DS161/AB/R (December 11 2000), para. 164.

Ibid., para. 166.

S. Thomas, 'Trade and Environment under WTO rules after the Appellate Body Report in Brazil Retreaded Tyres', Journal of International Commercial Law and Technology, vol. 4, no. 1, (2009), pp. 42-49, at 46.

EC-Asbestos, supra note 65, para. 170.

M. Andenas and S. Zleptnig (2007), supra note 44, at 411.

Thailand-Restrictions on the Importation of and Internal Taxes on Cigarettes, DS10/R - 37S/200

(November 7 1990), para. 75.

US-Gasoline, WT/DS2/R (January 29 1996), para. 6.25.

US-Gambling, supra note 57.

Ibid., para. 305. 
In US-Gambling, the AB reiterated the reasoning developed in Korea-Beef in that the 'necessary' condition should be determined through 'a process of weighing and balancing a series of factors. ${ }^{75}$ First the "relative importance, ${ }^{76}$ of the interests or values furthered by the challenged measures shall be assessed. In the same way as in the application of GATT Article $\mathrm{XX}$, even if a less-restrictive measure is available, WTO Members may not be required to use it if its administrative or enforcement costs are excessive. ${ }^{77}$ The report also stated that a measure that preserves the responding party's right to achieve its desired level of protection (with respect to GATS Article XIV(a)) is a 'reasonably available' alternative measure. ${ }^{78}$ Some commentators have noted that, similarly to GATT Article XX, the application of the balancing test by the $\mathrm{AB}$ is self-contradictory. ${ }^{79}$

The US-Gambling approach has been followed by the AB in China-Audiovisuals. ${ }^{80}$ The AB clarified that the respondent bears the burden of proof to show that the chosen inconsistent measure is 'necessary'. Only when the complainant suggests an alternative measure, must the respondent show why "the proposed alternative is not genuine or is not "reasonably available" to confirm that the original measure is necessary'. ${ }^{81}$ China-Audiovisuals was the first case ever where the Appellate Body accepted the existence of less intrusive measures as proposed by the complaining party, obliging China to change its legislation on censorship.

The necessity test post-Korea-Beef thus resembles proportionality analysis so much that scholars have considered the principle of proportionality to belong to prominent principles in WTO law, based on examples of the necessity test. ${ }^{82}$ However, the majority of WTO lawyers do not agree that the necessity test and proportionality analysis are equivalent. The focus on least trade-restrictive measures has caused some criticism in academic literature, mainly because it imposes too many constraints on legitimate domestic policy choices. In the interpretation of Andenas and Zleptnig, the judicial development of the necessity test in WTO law has evolved from a least trade-restrictive approach, to a less trade-restrictive one, supplemented by a proportionality test. In sum, the necessity test introduces the possibility of flexible balancing into Article XX GATT (and Article XIV GATS) and a 'certain degree of subjectivity on the part of the judiciary'. ${ }^{83}$

\section{The Cost-Benefit Balancing Test}

Brazil-Retreaded Tyres constitutes a turning point for the necessity test and for proportionality: the panel report suggests that the necessity of a measure may depend on the character of the goal it pursues, ${ }^{84}$ and the report of the Appellate Body appears to entrench for the first time the need for a panel to take the importance of a regulatory goal into

\footnotetext{
$75 \quad$ Ibid., para. 305.

$76 \quad$ Ibid., para. 306.

$77 \quad$ Ibid., para. 308.

78 Ibid.

79 See for instance D. H. Regan, 'The Meaning of 'Necessary' in GATT Article XX and GATS Article XIV: The Myth of Cost-Benefit Balancing', World Trade Review, vol. 6, no. 3, (2007), 347-369. China-Measures Affecting Trading Rights and Distribution Services for Certain Publications and Audiovisual Entertainment Products, WT/DS363/AB/R (21 December 2009), para. 319.

US-Gambling, supra note 57, paras. 309-311.

See e.g. T. M. Franck (2010), supra note 2, at 237.

M. Andenas and S. Zleptnig (2007), supra note 44, at 411-12.

Brazil-Measures Affecting Imports of Retreaded Tyres, WT/DS332/AB/R (December 3 2007) para. 7.104.
} 
consideration. ${ }^{85}$ The report also recognizes that two measures may be cumulative, ${ }^{86}$ which increases the chance that the measures are considered necessary in the future. The Appellate Body emphasized that:

a panel must assess all the relevant factors, particularly the extent of the contribution to the achievement of a measure's objective and its trade restrictiveness, in the light of the importance of the interests or values at stake. ${ }^{87}$

Thus, the Appellate Body introduced a consideration of the importance of the policy goal of a measure in the context of necessity analysis. For many, this represents a step backwards, as it is considered inappropriate for panels to examine the importance of a regulatory goal, and because there is no methodology to guide the panels in their examination. ${ }^{88}$ Brazil-Retreaded Tyres has been criticized - among other things - for granting panels too much discretion with respect to determining the value of a specific national policy goal. ${ }^{89}$ At the same time, it constitutes a step towards a full proportionality test within the WTO framework, as it adds the kind of balancing and weighing of a goal, which was missing until then, and which distinguishes the necessity from the proportionality test. Nonetheless, doubts persist as to whether the DSB of the WTO is entitled to conduct such balancing and weighing of interests to the extent of proportionality stricto sensu for reasons indicated above.

\section{Safeguard Measures}

Article 5.1 of the Agreement on Safeguards establishes that a safeguard measure is to be applied only to the extent necessary to prevent or remedy a serious injury ${ }^{90}$ and to facilitate adjustment. The main purpose of the proportionality principle is to minimize the tradedistortive effects of safeguards by setting the maximum economic extent to which such actions may be applied. ${ }^{91}$ The locution 'to the extent necessary' covers both the elements of suitability and the least-trade restrictiveness. Moreover, the measure has to be necessary 'to prevent or remedy', in other words, to correct or preclude serious injury to the importing country that produces like or competing products. The test, subject to more detailed provision on quantitative restrictions, is comparable to criteria applicable under Article XX GATT, and which relate to the principle of proportionality in similar ways. However, no disciplines on safeguards have so far emerged under GATS.

Ibid., paras. 156 and 210.

Ibid., para. 7.169.

Ibid., para . 156.

See e.g. B. McGrady, 'Necessity Exceptions in WTO Law: Retreaded Tyres, Regulatory Purpose and Cumulative Regulatory Measures', Journal of International Economic Law, vol. 12, no. 1, (2008), 153173, at 163 .

Ibid., at 173; C. P. Brown and J. P. Trachtmann, 'Brazil - Measures Affecting Imports of Retreaded Tyres: A Balancing Act', World Trade Review, vol. 8, no. 1, (2009), 85-135; and on WTO adjudication P. Eeckhout, 'The Scales of Trade - Reflections on the Growth and Functions of the WTO Adjudicative Branch', Journal of International Economic Law, vol. 13, no. 1, (2010), 3-26. 


\section{TBT and SPS Agreements}

The main standards in the Agreement on the Application of Sanitary and Phytosanitary Measures (SPS) and the Agreement on Technical Barriers to Trade (TBT) are that domestic measures shall pursue an accepted public policy objective and that they are no more traderestrictive than necessary. This involves a process of balancing and weighing 'aiming to ensure that the obstacles to international trade are not disproportionate or excessive to the objectives pursued by the Members'. ${ }^{92}$

In the SPS Agreement, such a domestic measure must be (i) 'necessary to protect human, animal or plant life or health' ${ }^{93}$ (while the word 'necessary' includes an obligation to show a causal link between the measure and the aim), and (ii) it must be rationally connected to an obligatory risk assessment ${ }^{94}$ (the rational connection relates to the risk at stake and not to the aim pursued). ${ }^{95}$ Furthermore, the domestic measure shall not be more trade-restrictive than necessary 'to achieve [the] appropriate level of sanitary or phytosanitary protection, taking into account technical and economic feasibility. ${ }^{96}$

Relating to Article 5.6 SPS Agreement, Australia-Salmon established a three-step test to assess an alternative SPS measure, which: (i) is reasonably available taking technical and economic feasibility into account, (ii) achieves the Member's appropriate level of sanitary and phytosanitary protection, and (iii) is significantly less restrictive to trade than the contested SPS measure. ${ }^{97}$ Mitchell suggests that this necessity test is comparable to the one used under GATT Article XX and may be considered as part of the general principle of proportionality. However, the emphasis on 'significantly' constitutes a slight shift in the standard, which may be seen as a proportionality tailored to the needs and logic of WTO law. ${ }^{98}$ According to Mitchell the TBT Agreement gives WTO dispute settlement bodies greater scope to account for proportionality than the GATT and the SPS Agreement. ${ }^{99}$ Based on Article 2.2 of the TBT Agreement, EC-Sardines established that WTO tribunals need to decide whether a Member's objective is legitimate, as well as whether it is suitable and necessary to achieve that objective. $^{100}$

U.S. - COOL and U.S. - Tuna II (Mexico), extensively addressed the issue of legitimacy. Firstly, it was confirmed that the legitimate objectives are not limited to an open list in Article 2.2 TBT Agreement. The panel in U.S. - COOL stated that there is no requirement that an objective pursued by a WTO Member State must be 'linked in nature' to those explicitly mentioned in Article 2.2 TBT Agreement. Although Canada objected to it, this approach not to apply the ejusdem generis principle was confirmed by the Appellate Body. ${ }^{101}$ With the reference to U.S. - Tuna II (Mexico) the Appellate Body recalled that the preamble of the

A. Desmedt (2001), supra note 49, at 424.

Article 2.1 SPS Agreement.

Article 5.1 SPS Agreement.

A. Desmedt (2001), supra note 49, at 455.

Article 5.6 SPS Agreement.

Australia-Salmon, WT/DS18/AB/R (October 20 1998), para. 180.

A. D. Mitchell (2008), supra note 45, at 201.

Ibid., at 202.

EC-Sardines, WT/DS231/AB/R (September 26 2002), para. 286.

U.S. - COOL, WT/DS384/AB/R; WT/DS386/AB/R (29 June 2012), para. 453. 
TBT Agreement, as well as other covered agreements may serve as a useful guidance or a source of information for the panel in determining what is 'legitimate'. ${ }^{102}$

In US-Clove Cigarettes the Panel suggested that GATT jurisprudence is relevant for the analysis of 'necessity', however, it does not suggest that it shall be applied in its entirety to the interpretation of Article 2.2 TBT Agreement. ${ }^{103}$ This approach was later supported by the panels and the Appellate Body in the US-Tuna II (Mexico) and US-COOL cases. ${ }^{104}$ The practice developed by the panels and the Appellate Body in cases on Article 2.2 TBT Agreement suggests that the necessity analysis is a 'relational analysis of the trade restrictiveness' based on assessment of the following factors. ${ }^{105}$ First, the panels need to consider: (i) trade restrictiveness of technical regulation; (ii) fulfilment of the objective pursued at the level chosen by a Member, which does not entail any minimum threshold and simply refers to a 'degree of contribution to the achievement of objective', ${ }^{106}$ and, finally, (iii) the risks of non-fulfilment, with due regard to the importance of the interests and values at stake. It should be noted that the wording of Article 2.2 TBT allows for some traderestrictiveness of the technical regulation, which, however, shall not constitute an unnecessary obstacle to trade. ${ }^{107}$ A positive obligation to ensure the proportionality of trade-restrictiveness differentiates the provisions of Article 2.2 TBT from Article XX GATT. Thus, in most of the cases ${ }^{108}$ the panel has to confirm 'necessity' of the trade-restrictiveness by comparing the challenged measure with the possible alternative measure and addressing (i) whether an alternative measure is less trade-restrictive; (ii) whether it would make an equivalent contribution to the legitimate objective; (iii) whether it is reasonably available, and, finally, (iv) what the risks of non-fulfilment of the legitimate objective are. ${ }^{109}$ Although, as demonstrated, there are two elements of necessity, all of the above-mentioned factors shall be considered and constitute a single 'necessity' analysis with a focus on the 'necessity' of trade restrictiveness under Article 2.2. TBT Agreement. ${ }^{110}$

\section{E. Scholarly Debate}

More than any other field of public international law, proportionality and necessity have triggered an intense doctrinal debate, comparable only to that in the field of investment protection. There is considerable disagreement among WTO scholars as to whether proportionality constitutes a general principle of WTO law. The existing opinions can be summarized in three different positions, which depend on the definition of proportionality

Ibid, para. 445 Trading Rights and Distribution Services for Certain Publications and Audiovisual Entertainment Products as well as to Art. 5.6 SPS Agreement, in US - Tuna II (Mexico)(PR), paras. 7.457-7.458, 7.471; U.S. - COOL (ABR), para. 374. the challenged measure does not contribute to the achievement of the legitimate objective. See: US Tuna II (Mexico), WT/DS381/AB/R (16 May 2012), fn. 647, para. 322. U.S. - COOL, para. 461; US - Tuna II (Mexico)(ABR), paras. 312-322. In 2008, Mitchell was already suggesting that Article 2.2 TBT Agreement may incorporate a proportionality stricto sensu test, whereas even the least trade-restrictive measure can violate the TBT Agreement if it is disproportional - see: A. D. Mitchell (2008), supra note 45, at 202. (ABR), para. 455.
} 
applied. Firstly, Hilf and Frank consider that proportionality is an underlying, general principle of WTO law, which 'helps to explain the evaluation of infringements of, or of exceptions to, WTO objectives, rules or disciplines'. ${ }^{111}$ According to Hilf, it essentially amounts to balancing competing rights. ${ }^{112}$ The author emphasizes that a 'sensitive balancing process, guided by the principle of proportionality is needed in which no rule or principle involved should be left to redundancy or inutility. The principle of proportionality should govern any process of interpretation and application of WTO law with a view to obtaining a due relation between the different interests at stake'. ${ }^{113}$

The second group of scholars argues that in limited cases, proportionality does indeed exist in WTO law, however, exactly where and to what extent remains disputed even among the scholars themselves. ${ }^{114}$

A third group refutes the principle of proportionality in WTO law and limits any balancing of rights and duties to the necessity test as established by the panel in Korea-Beef, ${ }^{115}$ which essentially establishes a three-step test of a least-trade restrictive measure. This group is the largest to date and bases its considerations on the fact that the panel is merely an organ which applies the treaty-texts and does not have any role in creating WTO rules. ${ }^{116}$ Jan Neumann and Elisabeth Türk argue that the WTO is not institutionally ready for a fundamental and systematic balancing of values and interests. ${ }^{117}$ Such balancing, however, is at the centre of the predominant proportionality analysis. A rather radical position is taken by Regan, as he refutes not only the application of the principle of proportionality under WTO law, but also the cost-benefit analysis:

\section{[The] word 'necessary' in GATT Article XX and GATS Article XIV suggests a less-restrictive alternative approach much more naturally than it suggests a cost-benefit balancing approach. Furthermore, $[\ldots]$ cost-benefit balancing is incompatible with the principle that Members get to choose their own level of protection. [...] None of these limitations requires cost-benefit balancing, and there is nothing else in the texts to suggest that the dispute system is authorized to subject measures to cost- benefit balancing. Judicial review by cost-benefit balancing is not in the spirit of the WTO. ${ }^{118}$}

There are various reasons for the disagreement among WTO lawyers concerning the role of proportionality in WTO law. As many of the accepted general principles of WTO law are also found in legal systems outside the WTO system, references to legal principles could be based

See M. Hilf, 'Power, Rules and Principles - Which Orientation for WTO/GATT Law?', Journal of International Economic Law, vol. 4, no. 1, (2001), 111-130; T. M. Franck (2010) supra note 2. Ibid., at 120. Ibid., at 130.

See A. D. Mitchell (2007), supra note 48; A. Desmedt (2001), supra note 49, 441-480; M. Andenas and S. Zleptnig, (2007), supra note 44, 371-427; J. Neumann and E. Türk, 'Necessity Revisited: Proportionality in World Trade Organization Law After Korea - Beef, EC - Asbestos and EC Sardines', Journal of World Trade, vol. 37, no. 1, (2003), 199-233. Korea-Beef, supra note 66. See S. Thomas (2009), supra note 68, at 42-49; B. McGrady, 'Necessity Exceptions in WTO Law: Retreaded Tyres, Regulatory Purpose and Cumulative Regulatory Measures', Journal of International Economic Law, vol. 12, no. 1, (2008), at 153-173. 
on the treaty-texts, but also based on sources of law outside the WTO system. Therefore, it is unclear whether, through application of a certain principle not explicitly mentioned in the text, the Appellate Body confirms that such a principle underlies WTO law or whether it is merely citing sources outside WTO law. ${ }^{119}$ This could be one of the doctrinal reasons for the disagreement among WTO lawyers on the relevance of the principle of proportionality in WTO law. Another more normative reason might be that WTO lawyers are concerned much less with the actual application of proportionality in WTO law than they are about the institutional consequences of general acceptance of proportionality as a principle in WTO law. They believe that the WTO is institutionally not ready for such a fundamental balancing of rights and interests. ${ }^{120}$ Gabrielle Marceau and Joel Trachtman argue that, on the one hand, balancing tests 'seem to some to accord too much power to courts'. ${ }^{121}$ On the other hand, balancing tests seem to 'intervene too greatly in national regulatory autonomy'. ${ }^{122}$ This lies at the heart of the problem. ${ }^{123}$

In conclusion, proportionality in WTO law is well-established in terms of necessity, i.e. the ability of less intrusive measures to contribute to the achievement of a particular aim, while additional tests of proportionality in terms of balancing and weighing different interests in assessing policy goals adopted by governments and the suitability of the measures adopted has remained controversial. The TBT and SPS Agreements go a step further than the other WTO agreements and establish positive normative standards to assess proportionality. The most recent jurisprudence on the TBT Agreement has built on the experience from the GATT, GATS and SPS Agreements, including the cost-benefit balancing, and offered the most comprehensive approach to the analysis of necessity in the WTO framework so far.

\section{Proportionality in Investment Law}

As a result of the negotiation of a patchy but extensive framework of international investment agreements (IIAs) worldwide, and more recently, the escalation in the use of investor-state arbitration procedures included in IIAs, investment has become one of the most prolific areas of international economic law and potentially of the proportionality doctrine. The application of IIAs, and treaty-based litigation in particular, has revealed a fundamental tension arising between two competing objectives. On the one hand are the various protection guarantees that IIAs seek to provide to foreign investors, and on the other, the regulatory powers that host States can and should exercise in pursuit of legitimate public policies. It is in the context of this intrinsic tension generated at the core of the application of certain provisions of IIAs that the principle of proportionality acquires its relevance.

\footnotetext{
$119 \quad$ M. Hilf (2001), supra note 111, at 121.

$120 \quad$ M. Andenas and S. Zleptnig (2007), supra note 44, at 373.

121 G. Marceau and J. Trachtman, 'The Technical Barriers to Trade Agreement, the Sanitary and Phytosanitary Measures Agreement, and the General Agreement on Tariffs and Trade' Journal of World Trade 36(5), (2002), 811-881, at 850-851. Ibid.

For an in-depth analysis of standards of review and therefore of the deliberate allocation of vertical powers between WTO adjudicating bodies and national authorities see e.g. M. Oesch, Standards of Review in WTO Dispute Resolution, Oxford University Press, Oxford, 2005.
} 


\section{A. Increasing Relevance}

Over the last two decades of practice in treaty-based investor-State disputes, the use of the proportionality principle as an analytical tool to interpret IIAs has been somewhat limited. This stems not only from the limited number of arbitration tribunals which have explicitly applied the principle, but also, from its timid invocation. Among those few tribunals which have explicitly invoked the proportionality principle in their analysis, very few have followed the rigorous step-by-step analytical procedure developed by the jurisprudence of various domestic and international courts. ${ }^{124}$

However, an overview of the evolution of investor-State arbitration case law shows that this is gradually changing. Arbitration tribunals are beginning to apply proportionality analysis in situations where the regulatory interests of host States have to be balanced vis-à-vis certain investment protection guarantees provided to foreign investors in IIAs.

In particular, the embryonic application of the principle of proportionality in the context of international investment law has taken place in three specific contexts. First, in the determination as to whether a particular regulatory measure constitutes a de facto expropriation. Second, whether a government action constitutes a violation of the fair and equitable treatment standard (FETS). And third, in the case of determining the correct applicability of clauses providing a general exception on public order and essential security interests - in particular, practice has focused on the application of various claims submitted by U.S. investors against Argentina under the bilateral investment treaty (BIT) between Argentina and the United States. After a brief synthesis of the contents of the principle, this section will illustrate how investor-State arbitration tribunals have applied the proportionality principle in the three contexts referred to above.

In the investment context, the application of the principle of proportionality entails a method of legal interpretation that is potentially suitable in situations of collisions or conflicts of interests of investors and of public policy objectives. ${ }^{125}$ For adjudicating disputes which involve conflicts between the legitimate interests of investors and competing public policy goals, proportionality has been considered the most appropriate analytical procedure. ${ }^{126}$ Yet, here as elsewhere, there are differences between the various versions and methodologies of proportionality analysis. They all represent a guiding structure for decision-makers in determining whether measures taken by public authorities have sufficiently taken into account the rights and interests of the subjects affected by those measures. ${ }^{127}$ However, not all aspects of IIAs are suitable for proportionality analysis. The following paragraphs illustrate the

Doctrine and comparative law in investment protection have recognized that the proper application of the principle of proportionality comprises observing the three guiding sub-principles identified in human rights protection and originating in German administrative law discussed above, text accompanying note 7 , that is, the principle of suitability, the principle of necessity and the principle of proportionality stricto sensu. See X. Han, 'The Application of the Principle of Proportionality in Tecmed v. Mexico', Chinese Journal of International Law, vol. 6, no. 3, (2007), pp. 635-652, at 636; B. Kingsbury and S. Schill, Investor-State Arbitration as Governance: Fair and Equitable Treatment, Proportionality and the Emerging Administrative Law, New York University Public Law and Legal Theory Working Papers, New York, (2009), at 29. B. Kingsbury and S. Schill (2009), supra note 124, at 21. 
conflicts of interest to which proportionality considerations apply, and how proportionality analysis has entered investment protection arbitration.

\section{B. Regulatory Takings}

Two types of expropriation covered by IIAs have to be distinguished: direct and indirect expropriations. In the case of direct expropriation (formal transfer of property rights), compensation is due, independent of the cause for the expropriation. In the case of indirect expropriation, and particularly in the case of regulatory takings, the situation is more complex: regulatory takings raise a conflict of interests between the regulatory interests of host governments and the investment protection interests of the investors. ${ }^{128}$

It should be noted, however, that under international law, not all regulatory interferences with property rights constitute an expropriation, and thus have to be compensated. In this regard, the Iran US Tribunal (IUSCTR) held in SEDCO ${ }^{129}$ that:

[i]t is also an accepted principle of international law that a State is not liable for economic injury which is a consequence of bona fide 'regulation' within the accepted police power of states. ${ }^{130}$

On the other hand, both doctrine and investment arbitration practice have considered that in certain circumstances, public regulation may lead to de facto expropriations. The NAFTA Tribunal in SD Myers, ${ }^{131}$ for example, stated in a case concerning temporary export provisions of dangerous waste:

[t]he general body of precedent usually does not treat regulatory action as amounting to expropriation. Regulatory conduct by public authorities is unlikely to be subject of legitimate complaint under Article 1110 [the norm regulating expropriations] of the NAFTA, although the Tribunal does not rule out that possibility. ${ }^{132}$

Thus, two doctrines dominate the jurisprudence of international arbitral tribunals on indirect takings: the 'sole-effects' doctrine under which the sole determining factor in deciding whether an indirect expropriation has occurred is the effect of the governmental measure on the investment. And the 'police-powers' doctrine, under which a range of other factors such as the purpose and context of the measure, the character of the measure and the interference in legitimate expectations of the investor, are considered. ${ }^{133}$

In Tecmed, ${ }^{134}$ an investment arbitration tribunal explicitly invoked the proportionality principle for the first time, leading to a combination of the two doctrines. The tribunal

U. Kriebaum, 'Privatising Human Rights: The Interface between International Investment Protection and Human Rights', in: A. Reinisch and U. Kriebaum (eds.), The Law of International Relations - Liber Amicorum Hanspeter Neuhaus, Eleven International Publishing, The Hague, (2007),165-189, at 178. SEDCO Inc. v. NIOC, Award, 24 October 1985, 9 IUSCTR 249.

SEDCO, supra note 129, at 275.

SD Myers, Inc. v. Government of Canada. Partial Award, 13 November 2000, 40 ILM (2001) 1408.

SD Myers, supra note 131 para. 281.

U. Kriebaum (2007) supra note 128, at 180; B. Kingsbury and S. Schill (2009) supra note 124, at 32. Tecnicas Medioambientales Tecmed SA v. The United Mexican States, Award, 29 May 2003, 43 ILM 133 (2004). 
attributed considerable weight to the effects of the measure, but also pondered additional factors when deciding whether a de facto expropriation had taken place. In Tecmed, the authorities had refused to renew an operating permit for a waste landfill. The ICSID Tribunal found that this failure constituted an expropriation. It also held that limitations on the use and enjoyment of benefits related to the property of permanent nature based on their actual effect can amount to a deprivation of such property, whereas the intention of the government is not decisive. Following the examination of the impact of the measure upon the investment, the Tribunal assessed whether the impact of the interference was proportional to the aim of the measure and to the investment protection granted. ${ }^{135}$ The determination as to whether the facts corresponded to a de facto expropriation was based on a two-step analysis. First, the tribunal determined whether the state's measure itself was sufficiently intense for a noncompensable regulation to turn into a compensable indirect expropriation. In this regard, it found that the waste disposal facility could not be used for a different purpose and could not be sold because of the pollution of the property. In a second step, the tribunal considered the effects of the non-renewal of the licence as only one factor among other aspects like the legitimate expectations of the investor, the importance of the regulatory interest pursued by the host state, the weight and the effect of the restriction, and other circumstances. ${ }^{136}$ The Tribunal ultimately found that the measure was not proportional.

With the inclusion of the assessment of proportionality, Tecmed was the first instance where a treaty-based investment arbitration explicitly mentioned the principle of proportionality. The proportionality test was applied to find out whether an expropriation had in fact taken place or not. A similar approach was later adopted in $L G \& E$ and in a few other cases. ${ }^{137}$ However, the proportionality principle has still not become widely used by investment arbitration tribunals in the determination of de facto expropriations.

\section{Application of the Fair and Equitable Treatment Standard}

One of the most frequently invoked standards of protection in investor-State arbitration is the 'fair and equitable treatment' standard (FETS). Such a standard, which is often worded in very vague terms, basically provides the investor with an absolute standard of protection separate from the host country domestic legislation. It does not entail an obligation of result, but rather an obligation of conduct on the part of the host government when implementing its administrative or legislative measures, which may affect the foreign investors. Due process, transparency, stability in the regulatory framework and the protection of the investor's legitimate expectations, constitute the main elements that investment arbitration has ascribed to the FETS. Within this context, the FETS often leads to situations where the proportionality principle can be useful to balance tensions between an investor's rights and a state's legitimate interest in regulating for the public good. ${ }^{138}$

FETS is particularly relevant for the protection of the investor's legitimate expectations. Because not every change of the domestic legal framework can result in the state's obligation

Ibid., para. 122, footnotes omitted.

B. Kingsbury and S. Schill (2009), supra note 124, at 33-5.

LG\&E Energy Corp., LG\&E Capital Corp., LG\&E International, Inc. v. Argentine Republic (ICSID

Case No. ARB/02/1), Award of 25 July 2007. See on proportionality analysis in the cases of indirect expropriation: C. Henckels, 'Indirect Expropriation and the Right to Regulate: Revisiting Proportionality Analysis and the Standard of Review in Investor-State Arbitration', Journal of International Economic Law, vol. 15, no. 1, (2012), 223-255.

A. S. Sweet (2010), supra note 126, at 13-14. 
to pay the investor compensation, a test is needed for balancing the different interests at stake. In Saluka, ${ }^{139}$ the tribunal warned about taking the idea of investor's expectations too literally, as this would impose unrealistic obligations upon states. ${ }^{140}$ The tribunal set out to balance the interests of the investor and the interests of the state within a broader proportionality test;

No investor may reasonably expect that the circumstances prevailing at the time the investment is made remain totally unchanged. ... The determination of a breach of Article 3.1 by the Czech Republic therefore requires a weighing of the Claimant's legitimate and reasonable expectations on the one hand and the Respondent's legitimate regulatory interests on the other. A foreign investor protected by the Treaty may in any case properly expect that the Czech Republic implements its policies bona fide by conduct that is, as far as it affects the investor's investment, reasonably justifiable by public policies and that such conduct does not manifestly violate requirements of consistency, transparency, even-handedness and nondiscrimination. In particular, any differential treatment of a foreign investor must not be based on unreasonable distinctions and demands, and must be justified by showing that it bears a reasonable relationship to rational policies not motivated by a preference for other investments over the foreign-owned investment. $^{141}$

This approach has been endorsed by various other tribunals. ${ }^{142}$ Tribunals increasingly also link proportionality with concepts of reasonableness. The cases of Pope \& Talbot ${ }^{143}$ and Eureko $^{144}$ both imported a general concept of reasonableness into specific interpretations and applications of FETS. On the other hand, proportionality-related analysis can also be relevant in establishing whether the exercise of administrative discretion conforms to FETS. ${ }^{145}$ In Middle East Cement, ${ }^{146}$ a key question was whether the procedural implementation of an auction was valid, particularly, whether sufficient notice of the seizure of the auctioned ship was given. Relying on the FETS in interpreting the due process requirement in the expropriation provision of the Greece-Egypt BIT, the tribunal reasoned that a direct communication on such an important matter would be necessary whether or not there is a respective obligation or commercial practice. ${ }^{147}$ Kingsbury and Schill state in this context, that, without formulating it explicitly, a proportionality analysis was applied by weighing the

Saluka Investments BV (The Netherlands) v. The Czech Republic, UNCITRAL Partial Award of 17 March 2006.

Saluka, supra note 139, para. 305.

Ibid., paras. 305 et seq.

See BG Group Plc. v. The Republic of Argentina, UNCITRAL Final Award of 27 December 2007, para. 298; or Marvin Feldman v. Mexico (ICSID Case No. ARB(AF)/99/1), Award of 16 December 2002, para. 111.

Pope \& Talbot Inc. v. Government of Canada, NAFTA Interim Award of 26 June 2000 (Media Copy), para. 68.

Eureko B.V. v. Republic of Poland, Partial Award of 19 August 2005, para. 233.

See B. Kingsbury and S. Schill (2009), supra note 124, at 38.

Middle East Cement Shipping and Handling Co SA v. Arab Republic of Egypt (ICSID Case No.

ARB/99/6), Award of 12 April 2002.

ME Cement, supra note 146, para. 143. 
importance of investment protection, the legitimate government interest pursued, and the fact that less restrictive but equally efficient options were available. ${ }^{148}$

\section{General Exceptions on Public Order and Essential Security Interests}

Another context in which the embryonic application of the principle of proportionality has taken place is in the determination of the correct invocation of clauses providing general public order or essential security exceptions in IIAs. The 1990s in Argentina were marked by deep market-oriented reforms, leading to a significant influx of foreign investment. In the early stages the negotiation of contracts occurred with extensive involvement of public authorities in a number of sectors, including utilities. The Argentinean Peso was pegged to the U.S. dollar to ensure economic stability in the country. During the years 1999-2002 the Argentinean economy suffered from a major economic meltdown, which resulted among other things in the devaluation of the currency. This in turn led to the devaluation of investments based on the initial exchange rate. The modification of the regulatory regime resulted in a wave of claims submitted to investor-State arbitration by U.S. and European investors under their respective BITs. ${ }^{149}$

The BIT between Argentina and the United States, includes Article XI which reads as follows:

This Treaty shall not preclude the application by either party of measures necessary for the maintenance of public order, the fulfilment of its obligations with respect to the maintenance or restoration of international peace or security, or the protection of its own essential security interests. ${ }^{150}$

Consequently, if measures undertaken by the Argentinean Government during the crisis meet the requirements outlined in Article XI, they do not breach rights provided to investors in other parts of the BIT. Thus, not surprisingly, in many cases, Argentina invoked Article XI as a defence against the claims submitted by foreign investors.

Arbitration tribunals have been quite inconsistent in their approaches towards evaluating the question of the legitimacy of measures necessary for the preservation of public order and security. Sweet argues that the proportionality test would be the best-practice standard for dealing with normative conflicts like the ones posed by a clause like this. ${ }^{151}$ However, arbitration tribunals have tended to ignore proportionality. Among several awards $C M S^{152}$ (May 2005), Enron ${ }^{153}$ (May 2007), LG\&E $E^{154}$ (July 2007), Sempra ${ }^{155}$ (September 2007), and

B. Kingsbury and S. Schill (2009), supra note 124, at 39.

A. S. Sweet (2010), supra note 126, at 19-20.

Treaty between the United States of America and the Argentine Republic Concerning the Reciprocal Encouragement and Protection of Investment (entered into force 20 October 1994). A. S. Sweet (2010), supra note 126, at 2. CMS Gas Transmission Company v. The Argentine Republic (ICSID Case No. ARB/01/8), Award of 12 May 2005. Enron Corporation Ponderosa Assets, L.P. v. Argentine Republic (ICSID Case No. ARB/01/3), Award of 22 May 2007. Case No. AEB/01/1), Award of 25 July 2007. 
Continental Casualty ${ }^{156}$ (September 2008), only the last undertook an explicit application of proportionality analysis. In Continental Casualty, ${ }^{157}$ the tribunal accepted the plea of Argentina under Article XI of the BIT and adopted a mature form of proportionality analysis. The proportionality test applied was the one developed by the GATT panels and the Appellate Body for dealing with derogations to the GATT permitted under Article XX of that agreement. $^{158}$

The tribunal began with establishing whether Article XI was applicable to the dispute. It ruled that significant economic and social difficulties may also require governmental actions to restore civil peace and the normal life of society, which correspondingly will fall under Article XI. ${ }^{159}$ The tribunal itself then adopted the standards and methodology used by WTO to adjudicate the necessity plea under Article XX GATT. The tribunal quoted the classic case Korea-Beef ${ }^{160}$ and stated that it is well-established that 'necessary' refers more to an 'indispensable' measure than to a measure 'making a contribution'. ${ }^{161}$ The tribunal finally turned to the analysis of necessity itself and quoted extensively from what today is a leading WTO case, Brazil-Retreaded Tyres discussed above in part IV.B.3:

The necessity of a measure should be determined through 'a process of weighing and balancing of factors' which usually includes the assessment of the following three factors: the relative importance of interests or values furthered by the challenged measures, the contribution of the measure to the realization of the ends pursued by it and the restrictive impact of the measure on international commerce. ${ }^{162}$

The tribunal then assessed the state measures under review with regard to a long list of alternatives. With one minor exception, the tribunal found that Article XI indeed covered Argentina’s measures. In January 2009, Continental Casualty asked that an annulment committee be constituted. ${ }^{163}$

Through the Continental Casualty decision, proportionality has made a significant entrance into treaty-based investment arbitration. As the necessity defence is likely to become a regular feature of investor-State arbitration (particularly in times of economic and financial crisis), tribunals are likely to further embrace the proportionality framework in the future. At the same time, it is likely to attract criticism similar to that in the debate on WTO law addressing the balance of powers between government and international courts of arbitration in reviewing governmental policies. Indeed, Sweet, and others, suggest that this explains the earlier reluctance to engage in proportionality in former cases:

To adopt proportionality-style necessity analysis would place arbitrators in the position of the balancing judge as perhaps

Continental Casualty Company v. The Argentine Republic (ICSID Case No. ARB/03/9), Award of 5 September 2008. 
something quite different than arbitrators traditionally conceived. ${ }^{164}$

Despite such concerns, a growing sector of the doctrine has started to advocate the use of proportionality analysis as a potential instrument not only to foster the development of sound international investment law jurisprudence, but also to deal with the eroding legitimacy of the international investment regime resulting from an inconsistent case law based on not always clear and sophisticated legal reasoning. Kingsbury and Schill argue that proportionality analysis seems to be more rational and profound than the "II-know-it-when-I-see-it" type of reasoning', thus improving the accountability of arbitrators. Moreover, it allows the noninvestment-related interests of the third parties that will be affected by the decision to be taken into account. ${ }^{165}$

In conclusion, proportionality in investment protection increasingly attempts to balance the different and competing legitimate interests involved; this is comparable to the methodology and problems developed in WTO law. It particularly interesting that the protection of legitimate expectations - an emanation of good faith - is discussed in terms of proportionality and balancing rights and obligations.

\section{Assessment and Conclusions}

Proportionality in international law appears in different forms and contexts. While it plays a crucial role in the protection of human rights, adopting constitutional doctrines and often a three-tier test, other fields use the principle in a less sophisticated and sometimes obscure manner. It is interesting to note that proportionality finds its roots in the law of reprisals and in maritime boundary delimitation in the principle of equity. The former aimed at limiting reprisals to what is required to achieve particular goals, thus adopting the tests of necessity in view of an unchallenged governmental policy. In maritime boundary delimitation, the principle of equity led to application of weighing and balancing of factors, rather than of a strict equidistance rule. Subsequent case law develops proportionality into an ex post test assessing potential disproportionality in the correlation of coastal lengths and marine spaces allocated. The normative role of the principle in such constellations comes close to avoiding abuse of rights through disproportionate allocations of resources, while leaving States ample leeway in their operations. This seems equally true for other purely horizontal relations, particularly relating to the use of force and reprisals. Limiting proportionality to a requirement to avoid disproportionate reactions, or reactions out of proportion, implies a limitation of judicial review and of standards of review of acts of States.

The much more stringent role of proportionality in human rights protection, however, indicates that the principle assumes a more active part in legal relations which mainly affect private operators. The same is true in WTO law. While reluctant to openly refer to proportionality as a general principle of WTO law, perhaps even international law, panels and the Appellate Body mainly operate proportionality within the concept of necessity. The obligation to show and prove less stringent measures by the complaining party is at the heart of the test. Yet, different forms of proportionality exist within WTO law and may even gain weight in the future as judiciary continues to establish tests of balancing and weighing in the 
sense of proportionality stricto sensu. Proportionality may influence the interpretation of specific provisions in WTO law, and pose less of a danger to WTO Members pursuing legitimate policy choices than some other, vaguely defined tests would. But there is considerable concern about the question whether the WTO judiciary should be balancing at all. While some believe that the WTO will eventually develop its own form of proportionality test (because it is unavoidable to have a proportionality test established in a law which embodies conflicts of interest), others urge the WTO DSB to abandon balancing (because the DSB is not entitled to do so and the WTO system is not yet sufficiently democratic). The problem is similar in investment protection. Operators enjoy the right to investor-State arbitration, and tribunals are called upon to assess rights and obligations of States and private parties directly. Investment dispute settlement is opening up towards a more active role of proportionality and potentially a three-tier test developed in administrative law and human rights protection. ${ }^{166}$ The restrictions imposed upon the investors in pursuit of legitimate policy goals may be assessed using a three-tier approach.

These findings may essentially have two explanations.

Firstly, proportionality was not firmly anchored in Anglo-American and Anglo-Saxon law the two legal cultures which have had the strongest influence in public international law since World War II. It is not a coincidence that authors sceptical about proportionality often have a common law background. Doctrines of necessity and of reasonableness assume comparable, but not identical functions. It is only more recently, and mainly through international law, that the principle has been discussed and we witness its gradual acceptance.

Secondly, and perhaps more important, traditional public international law structurally dealt with horizontal relations between States while proportionality originates in vertical relations between authorities and individuals and what was called the law of police (Polizeirecht). Policing states was not originally a task of international law. It was limited to co-ordinating sovereignty and territorial jurisdiction. The advent of human rights protection, as well as protection of market access, non-discrimination and investment in international economic law, have introduced elements of vertical relations to the extent that states, in their horizontal relations, have increasingly addressed issues concerning vertical relations of States and foreign individuals, both humans and corporations. It results in mixed constellations of both horizontal and vertical relations. This evolution rendered the principle of proportionality suitable in specific areas of international law. At the same time, it remains controversial because these relations continue to entail horizontal relations where respect for policy space and sovereignty has been of paramount importance in the Westphalian system of nation states and proportionality is limited to assessing the relationship of ends and means. It is no coincidence that the scope and outreach of proportionality in WTO law and investment law has remained controversial and partly obscure as it entails increasing encroachment of and review of government policies affecting market access and foreign direct investment. It is also no coincidence that these issues mainly appear in areas which are subject to dispute resolution which is no longer subject to ad hoc agreements and consent of States concerned.

WTO law is of particular importance in assessing proportionality both in horizontal and vertical relations because it is subject to mandatory dispute settlement and enforcement. Panels and the Appellate Body are called upon to assess whether state conduct amounts to nullification and impairment of benefits under the DSU, a task mainly consisting of assessing 
the legality of trade-related measures. The role of proportionality is therefore closely linked to rules and principles of treaty interpretation, standards of review and, more broadly, the position and role of judicial dispute settlement within the multilateral trading system. The agreement stipulates that 'recommendations and rulings of the Dispute Settlement Body cannot add to or diminish the rights and obligations provided in the covered agreements'. ${ }^{167}$ Panels and the Appellate Body have consistently interpreted the text of the agreements primarily 'in accordance with the ordinary meaning of the words of the treaty' ${ }^{168}$ Panels and the Appellate Body follow the customary rules of treaty interpretation embodied in Article 31 of the Vienna Convention on the Law of Treaties. Practice is characterized by strong adherence to textual and contextual interpretation. ${ }^{169}$ They seek to refrain from judicial activism. Thus, in possibly applying proportionality and thus in weighing different rights and interests, panels and the Appellate Body are careful not to alter existing rights and obligations under the WTO Agreements. This framework sets the stage for the potential operation of proportionality in trade regulation: it is inherently linked to the powers and functions of panels and the Appellate Body. Extensive or restrictive recourse to proportionality directly affects and defines such powers in assessing governmental action. The same is true for bilateral investment dispute settlement under BITs, in particular private actor v. state arbitration. Governments are equally obliged to engage in dispute settlement and legitimacy and compliance largely depends whether the ruling remains in line with the text and purpose of the agreement in accordance with the principles of treaty interpretation.

The reluctance to embrace the language and rhetoric of proportionality, in the absence of positive law, may in substance be founded in the concern that proportionality, applying predominant doctrines, results in overall weighing and balancing, which in the end will erode market access and non-discrimination and give way to almost any competing government policy. The same is true for the risk of eroding investment protection and of human rights. Proportionality is a principle of great value and assistance. But it does not and cannot dispense with making value-based judgments one way or the other, and who should be entitled to make these judgments? Foremost, the problem of proportionality is a matter of defining the proper role of courts in a system of multilevel governance and of vertical checks and balances.

Indeed, at the heart of these debates is the quest for the proper role and power of international courts of law and arbitration. It should be recalled that the full principle of proportionality originates in domestic law assuming powerful constitutional courts entitled to review governmental policies. International courts are more restrained in doing so. The review of horizontal applications of proportionality shows a clear restriction to necessity or ex-post assessment of reasonableness. Likewise, review of necessity in terms of defining appropriate means to end relations is well established. More extended review has remained controversial, both in trade and investment, albeit courts are gradually moving towards more broadly defined operations of balancing interests and thus proportionality stricto sensu.

It should be recalled that this problem of judicial review is not limited to international law, but is of general nature. Constitutional law in federal states shows similar problems of defining how to review value judgments. While the three-tier test originating in administrative law

Article 3.2 and Article 19.2 of the DSU. See e.g. P. Van den Bossche, From Afterthought to Centerpiece: The WTO Appellate Body and its Rise to Prominence in the World Trading System, Maastricht Faculty of Law Working Paper 2005/1, Maastricht, (2005). See also A. Desmedt (2001), supra note 46, at 442.
} 
leaves this task to courts, more federalist approaches leave the assessment of public interests to political bodies and the democratic process, limiting proportionality to assessing the relationship of ends and means. This is typically the case in Swiss constitutional law. ${ }^{170}$ The point is that a doctrine of multilevel governance is warranted not only in international law, but also in domestic law rendering governance more coherent overall. ${ }^{171}$

Perhaps the most important insights relate to legal methodology. Similar to equity, the principle of proportionality does not entail a mechanical application of norms and rules, but seeks reasonable and fair results by taking recourse to factors and criteria which are identified in a particular context and brought to mutual bearing and relations. It is on the basis of such factors of real life that necessity can be assessed, or whenever the law allows for it, weighing and balancing of different factors and identified values are undertaken. Proportionality stands for a particular method of jurisprudence which can be shared on all layers of governance, including international law.

Given the increasing role of proportionality as a legal principle in different legal orders, it amounts to a legal principle recognized in international law under Article 38 of the Statute of the ICJ, essentially derived from the tradition of equity. A common denominator identified in all areas of international law examined relates to the requirements for a reasonable relationship between ends and means. Measures employed should not exceed what is necessary to achieve the goal set. Proportionality in terms of necessity, reasonable relationship between end and means and exclusion of excessive measures qualifies as a general principle of law applicable in international law, both in horizontal and vertical relations. Beyond that, however, the principle assumes different regulatory functions in different contexts, and recognition of proportionality as a principle of law and thus of international law will not bring about uniform and simplified applications beyond the common trait of necessity. There is no common ground to adopt proportionality stricto sensu as an implied requirement to balance and weigh interests involved as a general principle of law. This is particularly true where the principle seeks to assess underlying values or choices and thus is linked to more extended powers of the judiciary. The controversies in WTO law and inherent tensions with positive law offer a pertinent example showing that generalizations cannot be made. It cannot be simply a matter of applying a three-tier principle of proportionality, which was developed in a particular constitutional context and system of separation and balances of power which is not identical to the one found in international law. The foundation will, however, allow proportionality to develop its role and function in

See BGE 2C. 485/2010 (Glarner Sach Insurance).

See e.g. T. Cottier et al., 'Introduction: Fragmentation and Coherence in International Trade Regulation: Analysis and Conceptual Foundations’, in: T. Cottier and P. Delimatsis (eds.), The Prospects of International Trade Regulation: From Fragmentation to Coherence, Cambridge University Press, Cambridge, (2011), 1-65, at 33 et seq.; T. Cottier, 'The Impact from Without: International Law and the Structure of Federal Governance in Switzerland', in T. Cottier, P. Knoepfel and W. Linder (eds.), Verwaltung, Regierung und Verfassung im Wandel: Gedächtnisschrift für Raimund E. Germann, Helbing \& Lichtenhahn, Basel, (2000), 213-230; T. Cottier and M. Hertig, 'The Prospects of $21^{\text {st }}$ Century Constitutionalism', Max Planck Yearbook of United Nations Law, Martinus Nijhoff Publishers, Leiden and Boston , vol. 7, no. 1, (2003), 261-322, at 299; T. Cottier, 'The Constitutionalism of International Economic Law', in K.M. Meessen et al. (eds.), Economic Law as an Economic Good. Its Rule Function and its Tool Function in the Competition of Systems, Sellier de Gruyter, Munich, (2009); T. Cottier, 'Konstitutionalisierungsprobleme im internationalen Wirtschaftsrecht: verfassungsrechtliche Herausforderungen im Rahmen der WTO’, Recht, Zeitschrift für juristische Ausbildung und Praxis, Sonderheft: Die Öffnung des Verfassungsrechts. Symposium zum 65. Geburtstag von Prof. Jörg Paul Müller, (2005), 50-62, at 51-52. 
different aspects of international law, responding, ultimately, to the rules of reasonableness and fairness. 